\title{
ELECTROOXIDATION OF COCONUT OIL IN ALKALINE ELECTROLYTE
}

\author{
Paweł P. Włodarczyk ${ }^{1}$, Barbara Włodarczyk ${ }^{1}$ \\ 1 University of Opole, Faculty of Natural Sciences and Technology, Department of Process Engineering, \\ Dmowskiego Str. 7-9, 45-365 Opole, Poland, e-mail: pawel.wlodarczyk@uni.opole.pl, barbara.wlodarczyk@ \\ uni.opole.pl
}

Received: 2017.05.04 Accepted: 2017.08.01 Published: 2017.09.01

\begin{abstract}
Providing more and more energy is an essential task of the today's energetic industry. In the last few years, in addition to the traditional methods of energy production, alternative energy sources have been developing fast. One of the devices that can make use of these sources is a fuel cell. The fuel cells can be a power source of future mainly due to their high efficiency, low influence on environment and the possibility of powering with different fuels. Most often, fuel cells are powered by hydrogen. However, the problems with its cheap production and storage are the reason for the search for alternative fuels for fuel cells. It is important that the new fuel will be characterized by zero or low emission level. One of these fuels can be vegetable oil. The paper presents the measurements pertaining to electrooxidation of coconut oil emulsion on a smooth platinum electrode in an aqueous solution of $\mathrm{KOH}$. The electrochemical measurements were performed in a glass cell with AMEL System 5000 potentiostat. The obtained maximum current density is equal to $25 \mathrm{~mA} / \mathrm{cm}^{2}$. Therefore the coconut oil can be used as fuel for fuel cell provided that the temperature of process is kept above $303 \mathrm{~K}$.
\end{abstract}

Keywords: fuel cell, electrooxidation, coconut oil, renewable energy sources, environment engineering

\section{INTRODUCTION}

The energy consumption has increased greatly in recent years, mainly due to an improving standard of living. Currently, the energy production is generally based on coal, crude oil, natural gas or nuclear energy. Additionally, some alternative energy sources have been developed. One of the devices that can use these sources is a fuel cell (FC). The theoretical efficiency of a fuel cell can be equal to $100 \%$. In fact, the real efficiency varies between $40-80 \%$ [Stolten 2010, Hoogers 2004, O'Hayre at al. 2005]. Moreover, the fuel cells are characterized by zero or low negative influence on the environment and silent operation. Most often, fuel cells are powered by hydrogen [Hoogers 2004, Larminie and Dicks 2003, Rifkin 2003; Steele and Heinzel 2001, Stolten 2010]. However, problems with cheap production and storage of this fuel are the reason for the search of new fuels for FCs, also using biofuels [Hamnett 1997, Larminie and Dicks 2003, Milewski and Lewandowski 2013, Milewski at al. 2013, Ross 2006, Włodarczyk and Włodarczyk 2013, Włodarczyk and Włodarczyk 2016c, Włodarczyk and Włodarczyk 2016e, Włodarczyk and Włodarczyk 2017]. Vegetable oils can constitute one of such biofuels . Previous studies have shown a possibility of electrooxidation (in various electrolytes) of canola oil, sunflower oil or grape seed oil [Włodarczyk and Włodarczyk 2015a, Włodarczyk and Włodarczyk 2015b, Włodarczyk and Włodarczyk 2016a, Włodarczyk and Włodarczyk 2016b, Włodarczyk and Włodarczyk 2016d]. This paper presents the possibility of direct electrooxidation of coconut oil. Coconut oil is an oil extracted from the kernel or meat of mature coconuts harvested from the coconut palm and is produced in many countries [Marina at al. 2009]. Coconut oil is commonly 
used in cooking, especially for frying. It has been also tested for use as a feedstock for biodiesel to use as a fuel for a diesel engine [Alamu at al. 2010, Machacon at al. 2001]. Coconut oil has been tested for use as an engine lubricant, transformer oil and as fuel for diesel engines [Abeysundara at al. 2001, Alamu at al. 2010, Al-Widyan and Al-Shyoukh 2002, Lang at al. 2001]. The acids derived from coconut oil can be used as herbicides [James and Rahman 2005]. Moreover, it is employed in cosmetics production and for textile refinement. Thus, this oil has many uses [Marina at al. 2009, Shijna at al. 2015]. However, it is necessary to examine the possibility of using coconut as fuel for fuel cell. In this case, electrooxidation of coconut oil should be carried out to determine the basic possibility of electrooxidation of this substance.

Theoretically, current density can be described by the Butler-Volmer exponential function [Bockris and Reddy 2000].

$$
i=A \cdot i_{0} \cdot\left(e^{\left[\frac{\alpha_{a} n F}{R T}\left(E-E_{e q}\right)\right]}-e^{\left[-\frac{\alpha_{c} n F}{R T}\left(E-E_{e q}\right)\right]}\right)
$$

where: $i$-electrode current density $\left[\mathrm{A} / \mathrm{m}^{2}\right]$

$i_{0}-$ exchange current density $\left[\mathrm{A} / \mathrm{m}^{2}\right]$

$R$ - universal gas constant

$E$ - electromotive force at the terminals of the real cell $[\mathrm{V}]$

$E_{e q}$ - equilibrium potential [V]

$\alpha_{a}-$ the so-called anodic charge transfer coefficient

$\alpha_{c}-$ the so-called cathodic charge transfer coefficient;

$A$ - electrode active surface area $\left[\mathrm{m}^{2}\right]$

$n$ - number of electrons involved in the electrode reaction

$F$ - faraday constant per volt gram equivalent $[\mathrm{kJ}]$

or in a more compact form

$$
i=i_{0} \cdot e^{K \cdot \eta_{\text {act }}}
$$

where: $\eta_{\text {act }}-$ activation overpotential [V]

$K$ - the factor of dependence of activation overpotential on reaction speed

Unfortunately, despite extensive knowledge in the field of solid-state physics and kinetics of catalytic reactions, the implementation of the catalysts is carried out mainly experimentally.

\section{MATERIAL AND METHODS}

Coconut oil is a hydrophobic substance and does not conduct the electric current. In order to cause the conduction, an intermediate agent to dissolve coconut oil in water was used. Due to excellent emulsification properties, Syntanol DS10 was used as a detergent [Sakharov at al. 1975, Włodarczyk and Włodarczyk 2013, Włodarczyk and Włodarczyk 2015a, Włodarczyk and Włodarczyk 2015b, Włodarczyk and Włodarczyk 2016a, Włodarczyk and Włodarczyk 2016b, Włodarczyk and Włodarczyk 2016c, Włodarczyk and Włodarczyk 2016d, Włodarczyk and Włodarczyk 2016e, Włodarczyk and Włodarczyk 2017]. Syntanol DS-10 is characterized by high superficial activity, dispersion, solubilization capabilities and emulgation [Survila at al. 2005; Paraska and Karvan, 2010]. After electrooxidation of emulsion, Syntanol DS-10 can be degraded e.g. promoted by energy transfer reactions or by bacteria [Kravchenko at al. 1994, Ignatov at al. 1995].

The investigated coconut oil emulsion was obtained by mixing, in various ratios, the coconut oil, detergent and water, using a mechanical stirrer with the speed of about $1200 \mathrm{rpm}$ [Włodarczyk and Włodarczyk 2013, Włodarczyk and Włodarczyk 2015a, Włodarczyk and Włodarczyk 2015b, Włodarczyk and Włodarczyk 2016a, Włodarczyk and Włodarczyk 2016b, Włodarczyk and Włodarczyk 2016c, Włodarczyk and Włodarczyk 2016d, Włodarczyk and Włodarczyk 2016e, Włodarczyk and Włodarczyk 2017]. Emulsion stabilization time was about 20 minutes. The coconut oil and emulsion were heated during mixing. Coconut oil is a solid substance at room temperature. Therefore, the constant temperature of at least $298 \mathrm{~K}$ was maintained during measurements. Figure 1 shows view of coconut oil at temperature $293 \mathrm{~K}$ and $303 \mathrm{~K}$.

The measurements were done with the method of polarizing curves of coconut oil emulsion electrooxidation in glass vessel on a smooth platinum electrode in $\mathrm{KOH}$ electrolyte. Before the measurements were perfored, the electrode $(\mathrm{Pt})$ was degreased in $25 \%$ aqueous solution of $\mathrm{KOH}$, digested in acetic acid and washed with alcohol. Platinum was used as a catalyst of the working electrode, due to excellent catalytic properties, while saturated calomel electrode (SCE) was used as a reference electrode [Twigg 1989, Bockris and Reddy 2000, Holtzer and Staronka 2000]. The electrochemical measurements were performed in a glass cell with AMEL System 5000 potentiostat connected with a computer.

Figure 2 shows the scheme of research position for measurements of coconut oil emulsion electrooxidation. 


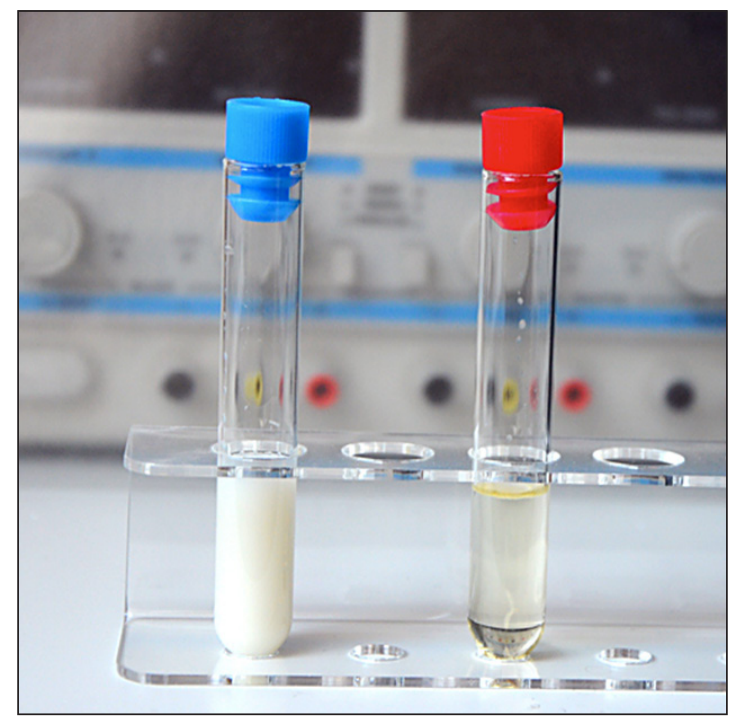

Figure 1. Coconut oil at temperature 293K (blue stopper) and at 303K (red stopper)

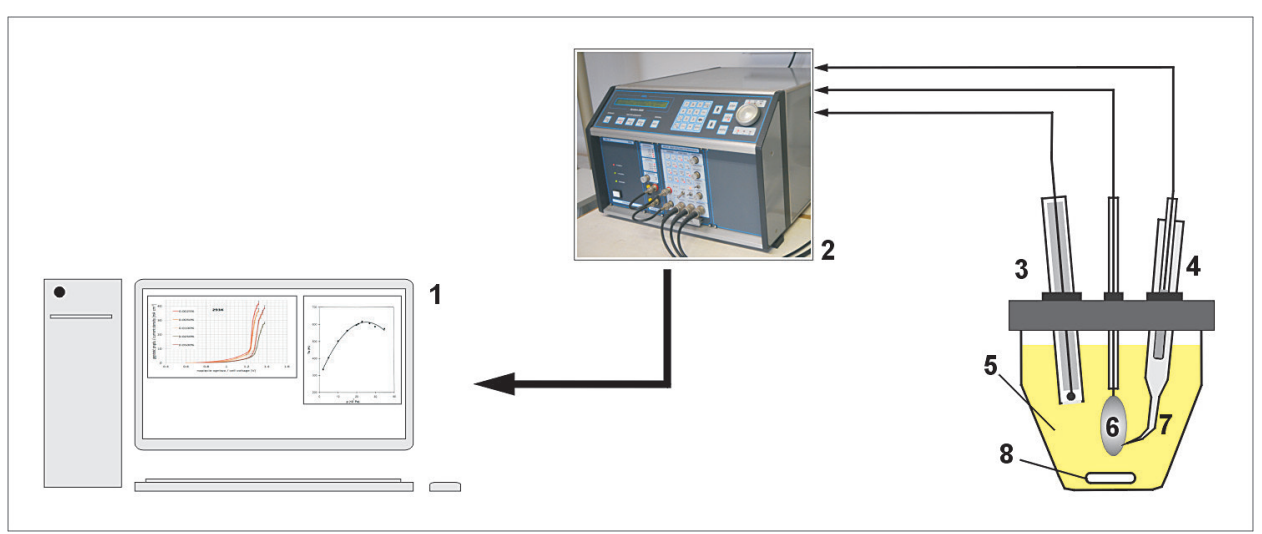

Figure 2. Scheme of research position for coconut oil emulsion electrooxidation: 1 - computer, 2 - potentiostat, 3 - auxiliary electrode, 4 - reference electrode (SCE), 5 - electrolyte $(2 \mathrm{M} \mathrm{KOH})$ with coconut oil emulsion, 6 - working electrode (Pt electrode), 7 - Luggin capillary, 8 - stirrer

The studies on electrooxidation of the emulsion based on coconut oil in an alkaline electrolyte (aqueous solution of $\mathrm{KOH}$ ), for various concentrations of oil and detergent, and at various temperatures $(303-348 \mathrm{~K})$ are presented in this paper.

\section{RESULTS}

The electrooxidation measurements of sole Syntanol DS-10 in alkaline electrolyte (aqueous solution of $\mathrm{KOH}$ ) were carried first. This measurement enabled to assess whether the current density was formed from the electrooxidation of coconut oil emulsion or only from the detergent. Figure 3-5 shows the polarization curves of coconut oil emulsion electrooxidation in various concentration of oil. The electrooxidation was carried out at the temperature of $303-348 \mathrm{~K}$.

\section{CONCLUSION}

The greatest difficulty throughout the study was keeping coconut oil emulsion at constant temperature above $303 \mathrm{~K}$, Because the oil solidified, and precipitated from the emulsion below this temperature. The potential of the working electrode was establishing in time of about 25 minutes and was badly reproducible. Stationary, current-free real potential depends on waste engine oil concentration and is included in potentials range from $0.59-1.11 \mathrm{~V}$.

The current density of about $6-20 \mathrm{~mA} / \mathrm{cm}^{2}$ was obtained for all concentrations of coconut oil. With the increase in temperature above $333 \mathrm{~K}$, the first electrooxidation of Syntanol DS-10 took place. Therefore, the current density obtained from electrooxidation of Syntanol DS-10 above temperature $340 \mathrm{~K}$ (fig. 6) was higher than cur- 


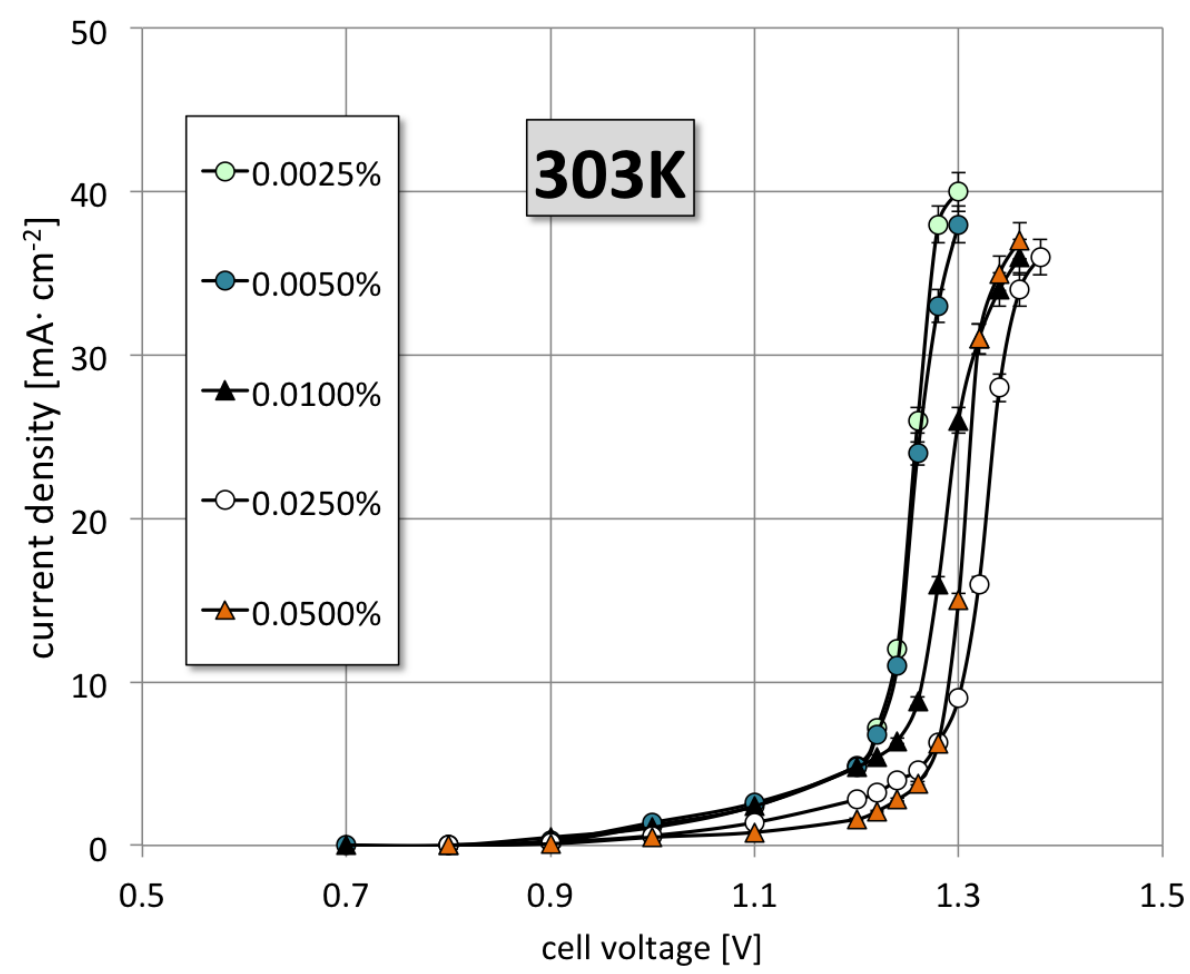

Figure 3. Polarization curves of coconut oil emulsion electrooxidation in $0,1 \mathrm{n}$ concentration of electrolyte $\mathrm{KOH}$ at temperature $303 \mathrm{~K}$; The concentration of coconut oil was equal to $0.0025 \% ; 0.0050 \% ; 0.0100 \% ; 0.025 \%$ and $0.0500 \%$

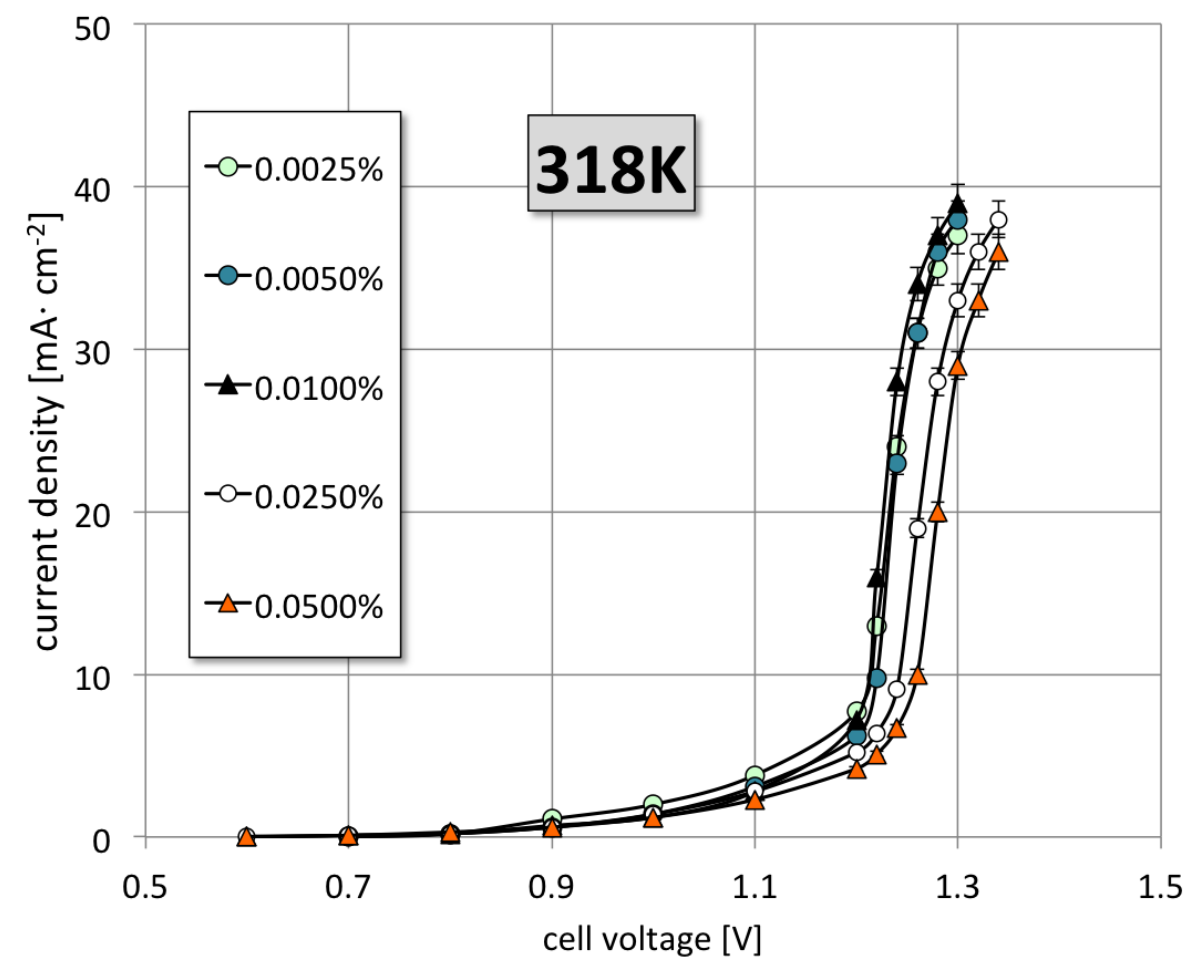

Figure 4. Polarization curves of coconut oil emulsion electrooxidation in 0 , 1n concentration of electrolyte $\mathrm{KOH}$ at temperature $318 \mathrm{~K}$; The concentration of coconut oil was equal to $0.0025 \% ; 0.0050 \% ; 0.0100 \% ; 0.025 \%$ and $0.0500 \%$ 


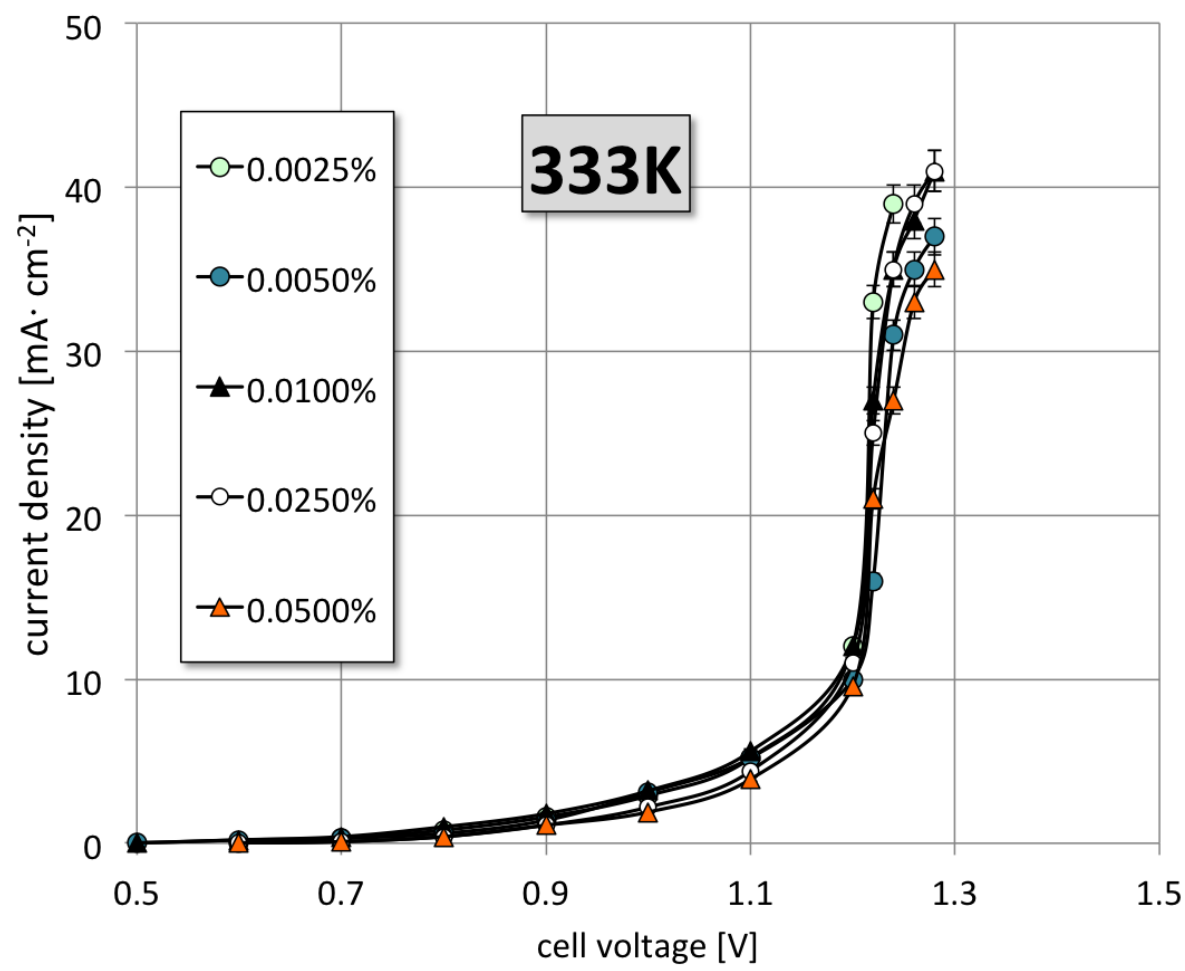

Figure 5. Polarization curves of coconut oil emulsion electrooxidation in 0 , 1n concentration of electrolyte $\mathrm{KOH}$ at temperature $333 \mathrm{~K}$; The concentration of coconut oil was equal to $0.0025 \% ; 0.0050 \% ; 0.0100 \% ; 0.025 \%$ and $0.0500 \%$

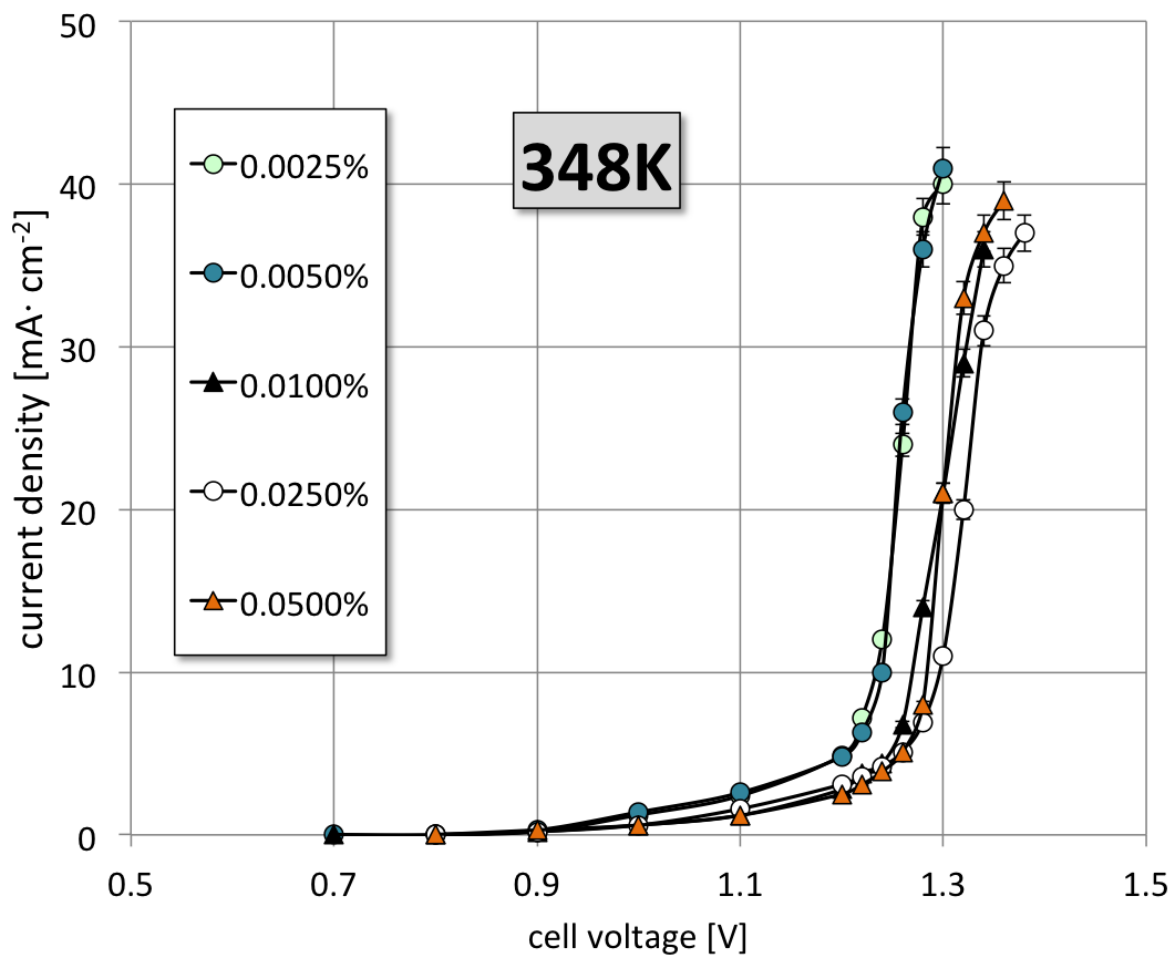

Figure 6. Polarization curves of coconut oil emulsion electrooxidation in $0,1 \mathrm{n}$ concentration of electrolyte $\mathrm{KOH}$ at temperature $348 \mathrm{~K}$; Concentration of coconut oil was equal to $0.0025 \% ; 0.0050 \% ; 0.0100 \% ; 0.025 \%$ and $0.0500 \%$ 
rent density obtained from electrooxidation of coconut oil emulsion. The highest results of the potential were obtained at the temperature of $333 \mathrm{~K}\left(25 \mathrm{~mA} / \mathrm{cm}^{2}\right)$ (fig. 5). Thus, the fundamental possibility of electrooxidation of coconut oil emulsion on platinum smooth electrode in acid electrolyte (aqueous solution of $\mathrm{KOH}$ ) was presented in this paper. The obtained current density and power of glass fuel cell is low, but it demonstrated a fundamental possibility of powering fuel cell with coconut oil.

\section{REFERENCES}

1. Abeysundara D.C., Weerakoon C., Lucas J.R., Gunatunga K.A.I., Obadagee K.C. 2001. Coconut Oil As An Alternative To Transformer Oil. ERU Symposium.

2. Alamu O.J., Dehinbo O., Sulaiman A.O. 2010. Production and Testing of Coconut Oil Biodiesel Fuel and its Blend. Leonardo Journal of Sciences, 16, 95-104.

3. Al-Widyan M.I., Al-Shyoukh A.O. 2002. Experimental evaluation of the transesterification of waste palm oil into biodiesel. Bioresour Technol., 85(3), 253-256.

4. Bockris J. O’M., Reddy A.K.N. 2000. Modern Electrochemistry. New York. Kulwer Academic/ Plenum Publishers.

5. Hamnett A. 1997. Mechanism and electrocatalysis in the direct methanol fuel cell. Catalysis Today, 38(4), 445-457.

6. Holtzer M., Staronka A. 2000. Physical Chemistry, Introduction (in Polish). Cracow. Publishing house AGH.

7. Hoogers G. 2003. Fuel Cell Technology Handbook. Boca Raton. CRC Press.

8. Ignatov O.V., Shalunova Iu.V., Panchenko L.V., Turkovskaia O.V., Ptichkina N.M. 1995. Degradation of Syntanol DS-10 by bacteria immobilized in polysaccharide gels (in Russian). Prikl Biokhim Mikrobiol., 31(2) 220-223.

9. James T.K., Rahman A. 2005. Efficacy of several organic herbicides and glyphosate formulations under simulated rainfall. New Zealand Plant Protection. 58, 157-163.

10. Kravchenko A.V., Rudnitskii A.G., Nesterenko A.F., Kublanovskii V.S. 1994. Degradation of Syntanol DS-10 promoted by energy transfer reactions. Ukrainian Chemistry Journal $\mathrm{C} / \mathrm{C}$ of Ukrainskii Khimicheskii Zhurnal, 60 (11) 11-13.

11. Lang X., Dalai A.K., Bakhshi N.N., Reaney M.J., Hert P.B.. 2001, Preparation and characterization of biodiesels from various biooils. Bioresces Technology, 80, 53-62.

12. Larminie J., Dicks A. 2003. Fuel cell system explained. John Wiley \& Sons Ltd.

13. Marina A.M., Che Man Y.B., Amin I. 2009. Virgin coconut oil: emerging functional food oil. Trends Food Sci Technol, 20(10), 481-487.

14. Marina A.M., Che Man Y.B., Nazimah A.H. 2009. Chemical properties of virgin coconut oil. J. Am. Oil Chem. Soc., 86, 301-307.

15. Milewski J., Lewandowski J. 2013. Biofuels as fuels for high temperature fuel cells. Journal of Power Technologies, 93(5), 347-353.

16. Milewski J., Michalska K. and Kacprzak A. 2013. Dairy biogas as fuel for a molten carbonate fuel cell-initial study. Journal of Power Technologies 93(3), 161-168.

17. Machacon H.T.C., Matsumoto Y., Ohkawara C., Shiga S., Karasawa T., Nakamura H. 2001. The effect of coconut oil and diesel fuel blends on diesel engine performance and exhaust emissions. JSAE Review, 22(3), 349-355. DOI: 10.1016/ S0389-4304(01)00111-4

18. O'Hayre R., Cha S-W., Colella W., Prinz F.B. 2005. Fuel Cell Fundamentals. Hoboken. John Wiley \& Sons.

19. Paraska O., Karvan S. 2010. Mathematical modelling in scientific researches of chemical technology processes. Technical Transactions. Mechanics. Cracow University of Technology Press, 107(2M), 203-210.

20. Ross D.K. 2006. Hydrogen storage: The major technological barrier to the development of hydrogen fuel cell cars. Vacuum 80 (10), 1084-1089.

21. Sakharov Iu.I., Rastiannikov E.G., Verbitskaia G.M. Tarasova L.N. 1975. Washability of Syntanol DS-10 from kitchen utensils (in Russian). Vopr Pitan. (4), 75-77.

22. Shijna K., Shirwaikar A., Shirwaikar A. 2015. Coconut Oil-A Review of Potential Applications Hygeia: Journal for Drugs and Medicines, 34-41. DOI:10.15254/H.J.D.Med.7.2015.149

23. Stolten D. 2010. Hydrogen and fuel cells. Fundamentals. Technologies and Applications. Weinheim. Wiley-VCH.

24. Survila A., Mockus Z., Kanapeckaite S., Samulevičienė M. 2005. Effect of Syntanol DS-10 and halides on tin(II) reduction kinetics. Electrochimica Acta, 50 (14), 2879-2885.

25. Twigg M.V. 1989. Catalyst handbook. London. Wolfe Publishing Ltd.

26. Włodarczyk P.P., Włodarczyk B. 2013. Powering fuel cell with crude oil. Journal of Power Technologies, 93(5), 394-396. 
27. Włodarczyk P. P., Włodarczyk B. 2015a. Electrooxidation of canola oil with Pt catalyst in acid electrolyte. Archives of Waste Management and Environmental Protection, 17(2), 18-28.

28. Włodarczyk P.P., Włodarczyk B. 2015b. Possibility of fuel cell powering with grape seed oil. QUAESTI-Virtual Multidisciplinary Conference, 3 (1), 300-304. DOI:10.18638/quaesti.2015.3.1.210

29. Włodarczyk P.P., Włodarczyk B. 2016a. Electrooxidation of sunflower oil in acid electrolyte. New Trends in Management and Production Engineering - Regional, Cross-border and Global Perspectives. Aachen. Shaker Verlag, 188-198.

30. Włodarczyk P.P., Włodarczyk B. 2016b. Canola oil electrooxidation in an aqueous solution of $\mathrm{KOH}-\mathrm{Pos}-$ sibility of alkaline fuel cell powering with canola oil. Journal of Power Technologies, 96 (6), 459-462.

31. Włodarczyk P.P., Włodarczyk B. 2016c. Elec- trooxidation of diesel fuel in alkaline electrolyte. Infrastructure and Ecology of Rural Areas, 4 (1), 1071-1080. DOI:http://dx.medra.org/10.14597/infraeco.2016.4.1.078.

32. Włodarczyk P.P., Włodarczyk B., 2016d. Canola oil electrooxidation in aqueous solution $\mathrm{NaCl}$ (in Polish). Diagnosing of the Environment Condition, Research Methods - Forecasts, Works of Ecology Commission and Environmental Protection, Scientific Society of Bydgoszcz, 10, 205-216.

33. Włodarczyk P.P., Włodarczyk B. 2016e. Direct electricity production from Avgas UL91 fuel. Civil engineering, 4th SCIECONF 2016, DOI:10.18638/ scieconf.2016.4.1.382.

34. Włodarczyk P.P., Włodarczyk B., 2017. Electrooxidation of used synthetic engine oil in aqueous solution of H2SO4 (in Polish), Ecological Engineering, 18 (1) 65-70. DOI:10.12912/23920629/66985 